Article

\title{
Combined Comparative Genomics and Gene Expression Analyses Provide Insights into the Terpene Synthases Inventory in Trichoderma
}

\author{
Isabel Vicente ${ }^{1,2, *}{ }^{\circledR}$, Riccardo Baroncelli ${ }^{2}\left(\mathbb{D}\right.$, María Eugenia Morán-Diez ${ }^{2}$, Rodolfo Bernardi ${ }^{1}$, \\ Grazia Puntoni $^{1}$, Rosa Hermosa ${ }^{2}\left(\mathbb{D}\right.$, Enrique Monte ${ }^{2}\left(\mathbb{D}\right.$, Giovanni Vannacci ${ }^{1}(\mathbb{D})$ and \\ Sabrina Sarrocco ${ }^{1}$ \\ 1 Department of Agriculture, Food and Environment, University of Pisa, 56124 Pisa, Italy; \\ rodolfo.bernardi@unipi.it (R.B.); grazia.puntoni@unipi.it (G.P.); giovanni.vannacci@unipi.it (G.V.); \\ sabrina.sarrocco@unipi.it (S.S.) \\ 2 Department of Microbiology and Genetics, Spanish-Portuguese Institute for Agricultural Research (CIALE), \\ University of Salamanca, Campus Villamayor, 37185 Salamanca, Spain; riccardobaroncelli@gmail.com (R.B.); \\ me.morandiez@gmail.com (M.E.M.-D.); rhp@usal.es (R.H.); emv@usal.es (E.M.) \\ * Correspondence: i.vicentemu@gmail.com; Tel.: +34-653-111-658
}

Received: 10 September 2020; Accepted: 16 October 2020; Published: 18 October 2020

check for updates

\begin{abstract}
Trichoderma is a fungal genus comprising species used as biocontrol agents in crop plant protection and with high value for industry. The beneficial effects of these species are supported by the secondary metabolites they produce. Terpenoid compounds are key players in the interaction of Trichoderma spp. with the environment and with their fungal and plant hosts; however, most of the terpene synthase (TS) genes involved in their biosynthesis have yet not been characterized. Here, we combined comparative genomics of TSs of 21 strains belonging to 17 Trichoderma spp., and gene expression studies on TSs using T. gamsii T6085 as a model. An overview of the diversity within the TS-gene family and the regulation of TS genes is provided. We identified 15 groups of TSs, and the presence of clade-specific enzymes revealed a variety of terpenoid chemotypes evolved to cover different ecological demands. We propose that functional differentiation of gene family members is the driver for the high number of TS genes found in the genomes of Trichoderma. Expression studies provide a picture in which different TS genes are regulated in many ways, which is a strong indication of different biological functions.
\end{abstract}

Keywords: functional gene differentiation; gene regulation; genomic characterization; terpene synthases; Trichoderma

\section{Introduction}

Trichoderma is a genus of ubiquitous fungi, comprising beneficious species used as biocontrol agents (BCAs) in crop plant protection due to their ability to antagonize and mycoparasitize a wide range of phytopathogens [1]. Some strains promote plant growth [2] and are also able to protect plants against pathogens indirectly by inducing the plant defense responses [3]. The beneficial effects of Trichoderma spp. are supported and often rely on the secondary metabolites (SMs) they produce [4-6], and the biological roles associated to these metabolites has been extensively reviewed [7-12]. These fungi produce a wide variety of SMs in a strain-dependent manner [13], with peptaibols, polyketides and terpenes as the most relevant [14].

Trichoderma spp. are reported to produce a broad diversity of terpenoids, including volatile compounds [15]. Terpenoids play important roles in the physiology of Trichoderma and in the interactions with other organisms, acting as toxins, chemical messengers, structural components of membranes, 
regulators of genes related to stress, and inducers of plant defense responses $[15,16]$. Despite their huge variety, all fungal terpenes are synthesized from few precursors by terpene synthase (TSs) enzymes. Isopentenyl-pyrophosphate and its isomer dimethyl-allyl pyrophosphate, both synthetized from acetyl-coA, are the five carbon (C) isoprene building blocks for the biosynthesis of linear polyprenyl pyrophosphates: C10 geranyl pyrophosphate (GPP), C15 farnesyl pyrophosphate (FPP) and C20 geranylgeranyl pyrophosphate (GGPP) [17]. These molecules are synthesized by the isoprenyl pyrophosphate synthases (IPSs) and constitute the precursors that undergo further modifications by terpene cyclases (TCs) and prenyl transferases (PTs), the core enzymes mediating the committed steps in terpenoid biosynthesis [18]. According to the origin of their scaffolds, terpenes can be distinguished in those exclusively formed by isoprenyl units (C10 monoterpenes, C15 sesquiterpenes, C20 diterpenes, C25 sesterterpenes and C30 triterpenes), and those of mixed origin (meroterpenoids, indole terpenoids and indole alkaloids).

Although many terpenes have been isolated from Trichoderma species, there is no extensive information about TS genes involved in their biosynthesis, and only a few members of the TS family have been experimentally characterized [19]. Functional characterization of TS genes in Trichoderma has been mainly focused on the trichodiene synthase (TRI5)-encoding gene, which catalyzes the first committed step in the biosynthesis of trichothecenes harzianum A and trichodermin in T. arundinaceum and T. brevicompactum, respectively [20-25]. Other Trichoderma TS genes experimentally characterized are erg-20 of T. reesei, encoding a farnesyl pyrophosphate synthase [26], and vir4, required for the biosynthesis of mono- and sesquiterpenes in T. virens [27]. Furthermore, genome mining studies have assessed the complete TS-gene family in Trichoderma, however, in those cases, the diversity of the genus has been mainly limited to three species-T. virens, T. atroviride and T. reesei [19], or the study has been merely quantitative [28-30].

Given the scarce information available about the diversity within the TS-gene family in Trichoderma, the first part of this work was focused on the genomic characterization of the whole TS arsenal of 21 strains belonging to 17 Trichoderma spp., thus covering a wide number of species with different lifestyles. This provides the most extensive overview of the terpenoid biosynthetic potential of the genus and reports the distribution of each class of TSs across the species. In addition, aimed at shedding some light on the environmental signals regulating the TS genes in Trichoderma, in the second part of the work we assessed the expression patterns of nine TSs in different conditions associated to the ecology of these fungi, using T. gamsii T6085 as a model. During the past 10 years, T. gamsii T6085 has been evaluated as BCA against Fusarium graminearum, the most aggressive causal agent of Fusarium Head Blight (FHB) on wheat. T6085 is able to reduce the growth of the pathogen as well as the production of deoxynivalenol (DON) [31,32], growing in the presence of high DON concentrations (50 ppm) and reducing FHB symptoms and the development of F. graminearum perithecia on wheat straw [33-36]. In addition, the fungus establishes a beneficial interaction with wheat roots, behaving as an endophyte and inducing the plant defense responses [36]. The versatile lifestyle of T. gamsii T6085 enabled us to investigate the TSs expression patterns in artificial media simulating stress conditions, as well as during the interaction of the fungus with wheat roots, and during the interaction with $F$. graminearum on wheat spikes, thus furnishing interesting novel results about the regulation of these genes and their role in the ecology of Trichoderma.

\section{Materials and Methods}

\subsection{Genomic Platform}

Genomes including gene annotation, available in public databases (National Center for Biotechnology Information [37]; Joint Genome Institute -JGI- [38], comprising 21 strains belonging to 17 Trichoderma species, were used for computational analyses (Table S1) [39-49]. Model organism Beauveria bassiana was used as outgroup due to its close phylogenetic relationship with Trichoderma spp. 


\subsection{Prediction of TS Proteins}

InterProScan v5.44-79.0 [50] was used to identify TS proteins in Trichoderma spp. and B. bassiana proteomes, based on the terms associated to their conserved domains (Isoprenoid synthase domain: IPR008949, Terpene cyclase/prenyl transferase domain: IPR008930). Pfam, PIRSF, Prosite, and Panther algorithms included in the interface, were used to identify motifs relatives to sites, superfamily membership, variants of prenyl transferase domains, and trans-membrane (TM) regions associated to TS proteins.

\subsection{Genomic Characterization of TS Proteins}

In order to characterize TS enzymes in Trichoderma spp. and B. bassiana we used a combination of different approaches: (i) PTs proteins were identified based on Pfam and Panther motifs, which in turn enabled differential identification of TCs proteins; (ii) conserved aspartate-rich metal-binding motifs associated to Class I (D[D/E]xx[D/E]) and Class II (DxDD) TS-folds [51] of mono- and bifunctional enzymes were identified searching for profile Hidden Markov Models (pHMM) in the amino-acidic sequences; (iii) substrate-specificity and putative functions were assigned by phylogenetic analysis: Trichoderma spp. and B. bassiana TS proteins were aligned by MAFFT v7.450 [52] along with TS proteins of known functions and described in literature (Table S2) [53-79]. Phylogenetic tree was built with: MrBayes [80], FasTree v2.1.11 [81] and PhyML v3.3.2 [82]. The best substitution model was obtained using ProtTest [83]. Phylogenetic tree was reconstructed using the WAG + I evolutionary model [84]. The probabilities and bootstrap values threshold were $50 \%$. Phylogenetic trees were visually checked and topology conservation evaluated. Sequences used for alignments and corresponding to each phylogenetic cluster identified were individually screened for conserved domains using InterProScan as described above.

\subsection{Fungal and Plant Material}

Trichoderma gamsii T6085 (Tgam) [42] and Fusarium graminearum ITEM 124 (Fgra) [85] were grown on PDA (Sigma-Aldrich, Milano, Italy) plates at $25^{\circ} \mathrm{C}, 12 \mathrm{~h} / 12 \mathrm{~h}$ light/darkness. Seeds from Triticum aestivum cv. Apogee (wheat) were sown in pots in a potting mix and incubated in a growth chamber with a photoperiod of $16 \mathrm{~h} \mathrm{light} / 8 \mathrm{~h}$ dark, at $20^{\circ} \mathrm{C} / 22{ }^{\circ} \mathrm{C}$. Before all experiments, wheat seeds were surface sterilized with a $\mathrm{NaClO}$ solution $(0.6 \%$ active chlorine) for $3 \mathrm{~min}$ on shaking, followed by three washing steps of $10 \mathrm{~min}$ each with sterile distilled water. Seeds were stored in sterile distilled water at $4{ }^{\circ} \mathrm{C}$ for 3 days for vernalization.

\subsection{Liquid Cultures of Tgam}

Mycelium of Tgam was obtained following a two-step liquid culture procedure. Spores of Tgam were collected from 1-week-old PDA plates and inoculated in $50 \mathrm{~mL}$ flasks containing $25 \mathrm{~mL}$ of minimal medium (MM) $0.9 \%$ sucrose $\left(9 \mathrm{~g} \mathrm{~L}^{-1}\right.$ sucrose-Panreac, Milan, Italy-, $1 \mathrm{~g} \mathrm{~L}^{-1} \mathrm{NH}_{4} \mathrm{NO}_{3}$-Carlo Erba, Milan, Italy-, $5 \mathrm{~g} \mathrm{~L}^{-1} \mathrm{C}_{4} \mathrm{H}_{12} \mathrm{~N}_{2} \mathrm{O}_{6}$-J.T. Baker, Milan, Italy-, $1 \mathrm{~g} \mathrm{~L}^{-1} \mathrm{~K}_{2} \mathrm{HPO}_{4}$-Carlo Erba, Milan, Italy-, $0.5 \mathrm{~g} \mathrm{~L}^{-1} \mathrm{MgSO}_{4}$-Carlo Erba, Milan, Italy-, $0.13 \mathrm{~g} \mathrm{~L}^{-1} \mathrm{CaCl}_{2}$-Panreac, Milan, Italy-, $0.1 \mathrm{~g} \mathrm{~L}^{-1}$ $\mathrm{NaCl}-$ Carlo Erba, Milan, Italy-, $0.0183 \mathrm{~g} \mathrm{~L}^{-1} \mathrm{FeSO}_{4}$-Carlo Erba, Milan, Italy-, $0.0035 \mathrm{~g} \mathrm{~L}^{-1} \mathrm{ZnSO}_{4}-\mathrm{J} . \mathrm{T}$. Baker, Milan, Italy-, $0.002 \mathrm{~g} \mathrm{~L}^{-1} \mathrm{MnCl}_{2}$-Carlo Erba, Milan, Italy-) at a final concentration of $10^{6}$ spores $\mathrm{ml}^{-1}$. Flasks were incubated at $28^{\circ} \mathrm{C}$ on a rotatory shaker at $180 \mathrm{rpm}$ for $60 \mathrm{~h}$. Mycelium was collected by centrifugation at 10,000 rpm for $10 \mathrm{~min}$ and supernatants were discarded. Mycelial pellet was resuspended in sterile distilled water and centrifugated at 10,000 rpm for $10 \mathrm{~min}$ to wash it. Mycelium was then inoculated in $50 \mathrm{~mL}$ flasks containing $25 \mathrm{~mL}$ of MM, MM $0.9 \%$ sucrose, and MM modified by adding different stressors, such as $0.5 \mathrm{mM} \mathrm{H}_{2} \mathrm{O}_{2}$ (Panreac, Milan, Italy), only $0.01 \%$ of $\mathrm{NH}_{4} \mathrm{NO}_{3}$ and $\mathrm{C}_{4} \mathrm{H}_{12} \mathrm{~N}_{2} \mathrm{O}_{6}$ (N starvation), and $200 \mathrm{mM} \mathrm{NaCl}$. Flasks were incubated at $28{ }^{\circ} \mathrm{C}$ on a rotatory shaker at $180 \mathrm{rpm}$ for 4 days. Mycelium was collected by filtration using Miracloth (475855-1R, Merk, Milan, 
Italy), frozen in liquid $\mathrm{N}_{2}$ and stored at $-80^{\circ} \mathrm{C}$ until RNA extraction. Three independent biological replicates were included for each condition.

\subsection{Tgam Interactions in FHB Scenario}

Wheat seeds were sown in pots in a potting mix (Esselunga, Pisa, Italy) and incubated in a growth chamber with a photoperiod of $16 \mathrm{~h} \mathrm{light} / 8 \mathrm{~h}$ dark, at $20^{\circ} \mathrm{C} / 22^{\circ} \mathrm{C}$ respectively, until plants reached the anthesis stage ( 5 weeks). Three biological replicates of three plants each were inoculated per each condition, i.e., Tgam alone, Fgra alone and Tgam + Fgra theses. For Tgam inoculation, spores were collected by washing 1-week-old PDA plates with $20 \mathrm{~mL}$ of sterile $0.01 \%$ Tween-80 (Carlo Erba, Milan, Italy) solution, and a $10^{7}$ spores $\mathrm{mL}^{-1}$ suspension was sprayed on spikes of Tgam alone and Tgam + Fgra plants. Plants were covered with a white bag, previously moistened inside with water to maintain humidity, and with a black bag to facilitate penetration by the fungus. Plants were incubated in a growth chamber for $48 \mathrm{~h}$ in the same conditions described above. For inoculation of the pathogen, conidia of Fgra were collected by washing 2-week-old PDA plates with $20 \mathrm{~mL}$ of sterile $0.01 \%$ Tween- 80 solution, and a $10^{5}$ spores $\mathrm{mL}^{-1}$ suspension was sprayed on spikes of Fgra alone and Tgam + Fgra plants. Plants were covered with a white bag, previously moistened inside with water, and a black bag was placed above to facilitate penetration by the pathogen. Plants were incubated in a growth chamber in the same conditions described above for an additional $24 \mathrm{~h}$. Bags were then removed for plant aeration and after $1 \mathrm{~h}$, white bags were placed back for an additional $24 \mathrm{~h}$. Six days after inoculation of $\mathrm{Fgra}$, from three to four spikes colonized by the fungi were collected from each biological replicate (10 spikes in total for each condition), frozen in liquid $\mathrm{N}_{2}$ and stored at $-80{ }^{\circ} \mathrm{C}$ until RNA extraction. Reduction of FHB symptoms was evaluated by calculating the percentage of healthy and symptomatic spikelets (Disease severity-DS) in Fgra alone and Fgra + Tgam plants. Differences on DS values were determined statistically by ANOVA after angular transformation, $(p$ value $(p) \leq 0.05)$ using SYSTAT@v.13.2 software.

\subsection{Tgam-Wheat Roots Interaction}

Four wheat seeds were placed on PDA at $1.5 \mathrm{~cm}$ distance from the center of the Petri dish. Plates were sealed with tape and incubated for $24 \mathrm{~h}$ at $22{ }^{\circ} \mathrm{C}$. After $24 \mathrm{~h}, 1 \mathrm{~cm}^{2}$ agar plug cut out at the border of 1-week-old colony of Tgam was placed in the center of the plates containing wheat seedlings, as well as in PDA plates without plants as controls. Plates were sealed with tape and incubated for 3 days in the same conditions described above. Wheat roots colonized by Tgam were collected, frozen in liquid $\mathrm{N}_{2}$ and stored at $-80^{\circ} \mathrm{C}$ until RNA extraction. Mycelium from Tgam PDA control plates was collected and stored until use. Three independent biological replicates were included for each condition.

\subsection{RNA Extraction and $c D N A$ Synthesis}

Fungal biomass from liquid cultures, wheat roots colonized by Tgam and fungal mycelium from the Tgam-root interaction control plates were ground in liquid $\mathrm{N}_{2}$ using pre-chilled mortar and pestle. Samples containing $100 \mathrm{mg}$ of powder were used for total RNA extraction using the RNeasy ${ }^{\circledR}$ Plant Mini Kit (Qiagen, Milan, Italy), according to the manufacturer's instructions. Wheat spikes colonized by the fungus were ground in liquid $\mathrm{N}_{2}$ using pre-chilled mortar and pestle. Samples containing $300 \mathrm{mg}$ of powder were used for total RNA extraction according to the method described by Logemann et al., 1987 [86]. RNA samples were treated with DNase I (DNase I Amplification Grade, AMPD1 Sigma-Aldrich, Milan, Italy) for gDNA removal, according to the manufacturer's instructions. A total of $400 \mathrm{ng}$ of RNA were used for cDNA synthesis using Maxima First Strand cDNA synthesis kit (K1642, Thermo Scientific, Milan, Italy) according to the manufacturer's instructions.

\subsection{Gene Expression Analyses}

Terpene synthases gene expression was analyzed by quantitative real-time PCR performed in Rotor-Gene Q cycler (Qiagen) with QuantiNova SYBER ${ }^{\circledR}$ Green PCR Master Mix 2X (Qiagen) (TS genes 
used for expression analysis are listed in Table 1). All PCR reactions were performed in triplicate (technical replicates) for each biological replicate in a total volume of $20 \mu \mathrm{L}$ for 40 cycles under the following conditions: initial activation, $95^{\circ} \mathrm{C}, 2 \mathrm{~min}$; 40 cycles of denaturation, $95^{\circ} \mathrm{C}$ for $5 \mathrm{~s}$ and combined annealing/extension, $60^{\circ} \mathrm{C}$ for $10 \mathrm{~s}$. Threshold cycles $(\mathrm{Ct})$ were calculated with Rotor-Gene Q Series Software 2.3.1 using the $\beta$-tubulin gene as endogenous control, which was selected due to its expression stability among other housekeeping genes (actin and transcription elongation factor-1 genes). Data were expressed as $2^{-\Delta \Delta C t}$ [87]. Values from three biological replicates were consistent and used for ANOVA statistical analysis, using SYSTAT@ ( v.13.2 software. Data from liquid cultures of Tgam were analysed by ANOVA and Tukey test $(p \leq 0.05)$ using SYSTAT@ $(13.2$ software. Primers used for assessing expression patterns of $t s 1, t s 3, t s 4, t s 5, t s 6, t s 7, t s 9, t s 11$, tri5 genes, and those of $\beta$-tubulin (Table S3) were checked for efficiency and dimmer formation.

Table 1. Terpene synthase genes found in the genome of T. gamsii T6085. JGI accession numbers of each protein are shown in the first column. Protein names are shown in the second column. Putative protein functions derived from computational analysis are shown in the third column. Terpene synthases used in gene expression analyzed are shown in bold.

\begin{tabular}{ccc}
\hline JGI Id. & Name & Putative function \\
\hline Trigam1|5596 & TC4 & bifunctional HAD-like \\
\hline Trigam1|4742 & TRI5 & trichodiene synthase \\
\hline Trigam1|162 & TS5 & pentalenene synthase \\
\hline Trigam1|9843 & TS7 & sesquiTS \\
\hline Trigam1|1824 & TS4 & sesquiTS \\
\hline Trigam1|4947 & TS3 & sesquiTS \\
\hline Trigam1|5367 & TS1 & uncharacterized 4 \\
\hline Trigam1|340 & TS6 & squalene synthase \\
\hline Trigam1|3208 & TC3 & GGTase I \\
\hline Trigam1|5139 & TC5 & GGTase II \\
\hline Trigam1|3927 & TC1 & FPP transferase \\
\hline Trigam1|4065 & TS8 & GGPP synthase \\
\hline Trigam1|2917 & TS10 & FPP synthase \\
\hline Trigam1|9898 & TS9 & indole diTS \\
\hline Trigam1|8345 & TC2 & oxidosqualene cyclase \\
\hline Trigam1|6072 & TS11 & uncharacterized 5 \\
\hline & &
\end{tabular}

\section{Results}

\subsection{Characterization of TSs Provides an Overview of the Terpenoid Biosynthetic Potential in Trichoderma}

We used an in-silico approach in order to assign putative functions to 387 TS-encoded proteins currently found in the genomes of Trichoderma spp., which were found distributed in 15 functional groups. TSs sharing conserved domains and metal-binding motifs clustered in the same phylogenetic group, each one highlighted in a different color (Figure 1). TSs accession numbers, TS-content per each species showing specific portions of the TS inventory, and phylogenetic tree including protein accession numbers are available in Table S4 and Figure S1. 


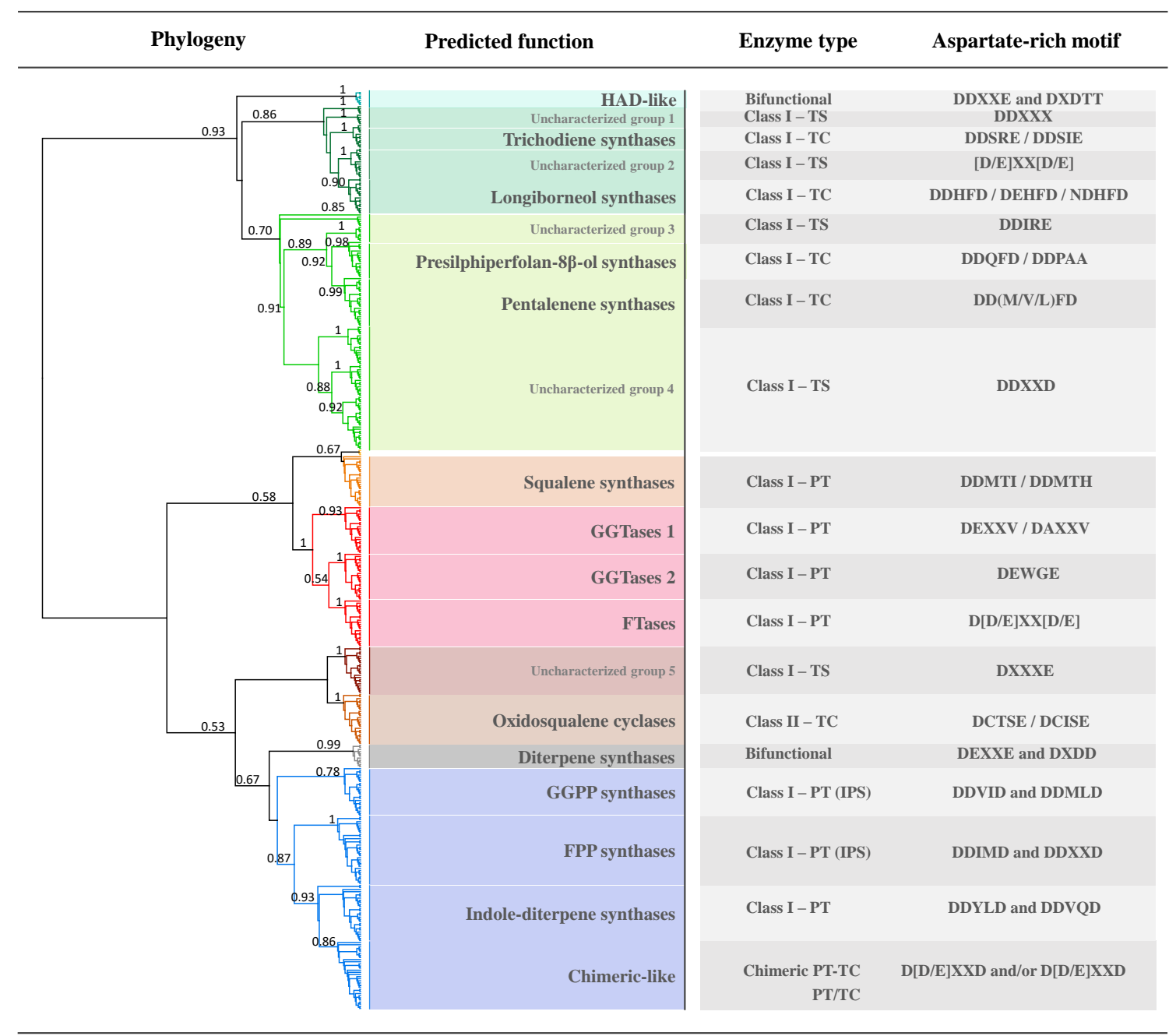

Figure 1. Genomic inventory for terpenoid biosynthesis in Trichoderma spp. Terpene synthase (TS) proteins sharing conserved domains are highlighted in different colors: HAD-like (light blue), TRI5 (dark green), terpene synthase C (light green), squalene synthase-phytoene synthase (orange), prenyl transferase (red), squalene/hopene cyclase (light and dark brown), kaurene synthase and/or ent-copalyl diphosphate synthase (grey), and polyprenyl synthase and/or TS C (dark blue). Putative functions of terpene cyclases (TCs) and prenyl transferases (PTs) were assigned based on phylogenetic analysis performed with terpene synthase proteins with known function from filamentous fungi (Table S2) [53-79]. Proteins which did not clustered with any known protein were designed as uncharacterized TSs. Aspartate-rich motifs of Class I, Class II and Bifunctional enzymes were identified in the amino-acidic sequences of each group of proteins. Bootstrap values $>50$ are shown in the correspondent branches of the tree.

Analysis revealed specific TSs sharing N-terminal HAD-like (Pfam 13419; PTHR43611:SF3) and C-terminal TS domains (IPR008930) (light blue color in Figure 1), which seems to be exclusive of species belonging to the clade Viride (Table S4). Although they did not cluster with known TSs, the presence of both Class I DDxxE and Class II DxDTT motifs indicates they are bifunctional enzymes.

We found a vast group of sesquiterpene synthases (sesquiTSs) belonging to the TRI5 superfamily (Pfam 06330) (dark green color in Figure 1), which was particularly represented in species of Viride clade (Table S4). It contains 7 TRI5 (PIRSF001388), 15 longiborneol synthases, and two groups of proteins that did not cluster with known TSs (uncharacterized group 1 and 2, respectively). The phylogenetic distribution of TRI5 (Table S4) indicates that it is not a monophyletic trait in Trichoderma, opening questions about its evolutionary origin. Species of clade Viride were the only lacking longiborneol 
synthases, however, they are rich in TSs of "uncharacterized groups 1 and 2", which can only be found in few species outside the clade Viride (Table S4).

The sister clade of the TRI5-superfamily group (light green color in Figure 1) contains Class I proteins sharing a conserved terpene synthase C domain (Pfam 03936), which can be found in sesquiTS and monoterpene synthases (monoTS). It contains two groups of sesquiTS including 16 presilphiperfolan- $8 \beta$-ol synthases, 22 pentalenene synthases and two groups of proteins that did not cluster with known TSs (uncharacterized groups 3 and 4, respectively) (Table S4). Presilphiperfolan-8 $\beta$-ol synthases are absent in Viride species, T. arundinaceum and T. atrobrunneum, whereas pentalenene synthases were found in all the genomes analysed (Table S4). Although most of these share highly conserved metal-binding motifs, some proteins lack the NSD/DTE triad but contain an additional DDxxD motif. This suggests they could actually synthesize sesquiterpenes others than pentalenene. TSs of "uncharacterized group 4" are widely distributed across species, but are particularly represented in T. virens and T. pleuroticola (Table S4). Differently, proteins of "uncharacterized group 3" seem to be exclusive to species belonging to the Harzianum clade, and their phylogenetic proximity to both groups of sesquiTS suggests this group is also composed by this type of TSs.

We found a large group of PTs, identified as squalene synthases (SQSs) (Pfam 00494; PTHR11626:SF2; PS01044) (orange color in Figure 1), showing the conserved TM helix region of 23 residues in their C-terminal [88], and enzymes involved in protein prenylation [89] (red color in Figure 1), such as type I geranylgeranyl transferases (GGTases 1) (PTHR11774:SF4), type II geranylgeranyl transferases (GGTases 2) (PTHR11774:SF11) and farnesyl transferases (FTases) (PTHR11774:SF6). They are present in single copy in the genomes of Trichoderma, but the additional SQS found in T. pleuroti indicates that at least one SQS is probably pathway-specific (Table S4).

Oxidosqualene cyclases (OSCs) (Pfam 13249; Pfam 13243; PTHR11764; PS01074) (light-brown color in Figure 1) are present in single copy in the genomes of Trichoderma, showing DCTSE or DCISE aspartate-rich motifs, both variants of the classical DCTAE reported in these proteins [75], and five conserved QW motifs responsible of strengthening the structure of the enzyme [90].

TSs from the sister clade of OSCs are in single copy in all the genomes and contain a conserved squalene synthase-phytoene synthase domain (Pfam 00494; PTHR21181:SF13) (dark brown color in Figure 1), but they did not cluster with SQSs and neither with reference lycopene-phytoene synthases (uncharacterized group 5).

Copalyl-pyrophosphate/Ent-kaurene synthases (CPS/KS) (PTHR31739:SF4; PIRSF 026498) (grey color in Figure 1) were found in T. asperellum, which known for its ability for gibberellin biosynthesis [91]. $\mathrm{CPS} / \mathrm{KS}$ clustered with other Class II bifunctional enzymes of species from clades Longibrachiatum and Brevicompactum (PTHR31739:SF4), but the low sequence similarity of these with CPS/KS indicates they are diterpene synthases (diTS) not involved in ent-kaurene biosynthesis.

The last cluster (dark blue color in Figure 1) contains proteins sharing a conserved polyprenyl synthase domain (Pfam 00348). Within this group, GGPP synthases (PTHR12001:SF47; PS00723; PS00444) and FPP synthases (PTHR11525:SF0; PS00723; PS00444) were identified, showing the two characteristic DDxxD motifs usually found on these enzymes [51,92]. Some species belonging to Harzianum and Brevicompactum clades have two to three copies of these PTs class, suggesting that at least some of them could be actually pathway-specific (Table S4). Analysis also revealed a set of highly conserved indole diTS, whose biosynthetic products have not been reported yet in Trichoderma. The last group contains Class I TSs clustering with known chimeric TSs from fungi (chimeric-like), which were absent in species of clade Viride. Most of them contain only polyprenyl synthase or TS $C$ domains. Nevertheless, we found one protein in T. asperellum TR456 containing both domains, which is highly similar to ophiobolin F synthase from Aspergillus clavatus, suggesting this specie is able to produce sesterterpenes. 
3.2. Assessment of the Genomic Context of tri5 Genes Reveals Its Potential Involvement in Unknown Biosynthetic Pathways in Trichoderma

The presence of tri5 orthologs in Trichoderma spp. that have not been described as trichotheceneproducers, such as T. gamsii, T. asperellum and T. guizhouense, suggests this gene could be involved in the biosynthesis of different trichodiene derivatives. Multi-sequence alignment of TRI5 proteins showed the active center is highly conserved, sharing DDSRE/DDSIE aspartate-rich motif and NDLFSFYKE triad (Figure 2a).

a)
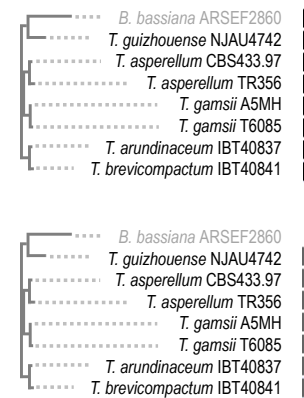

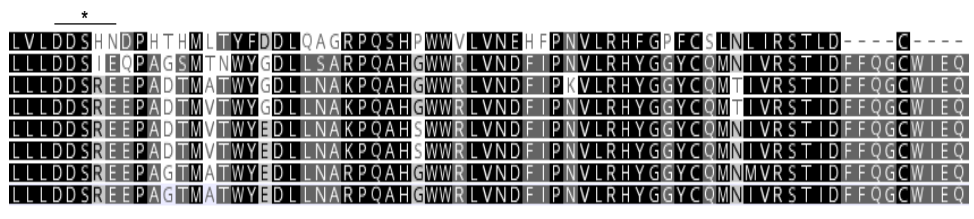

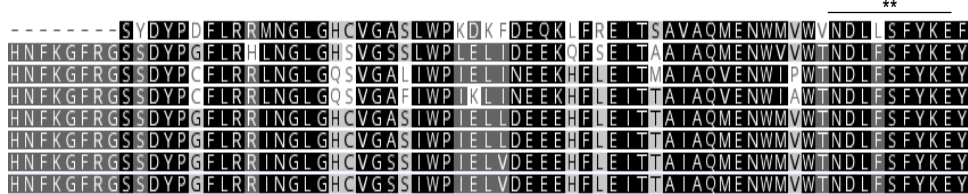

b)

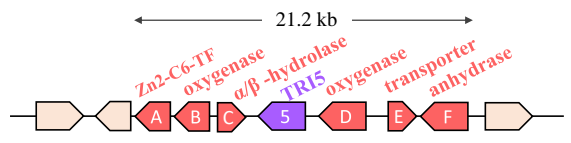

c)

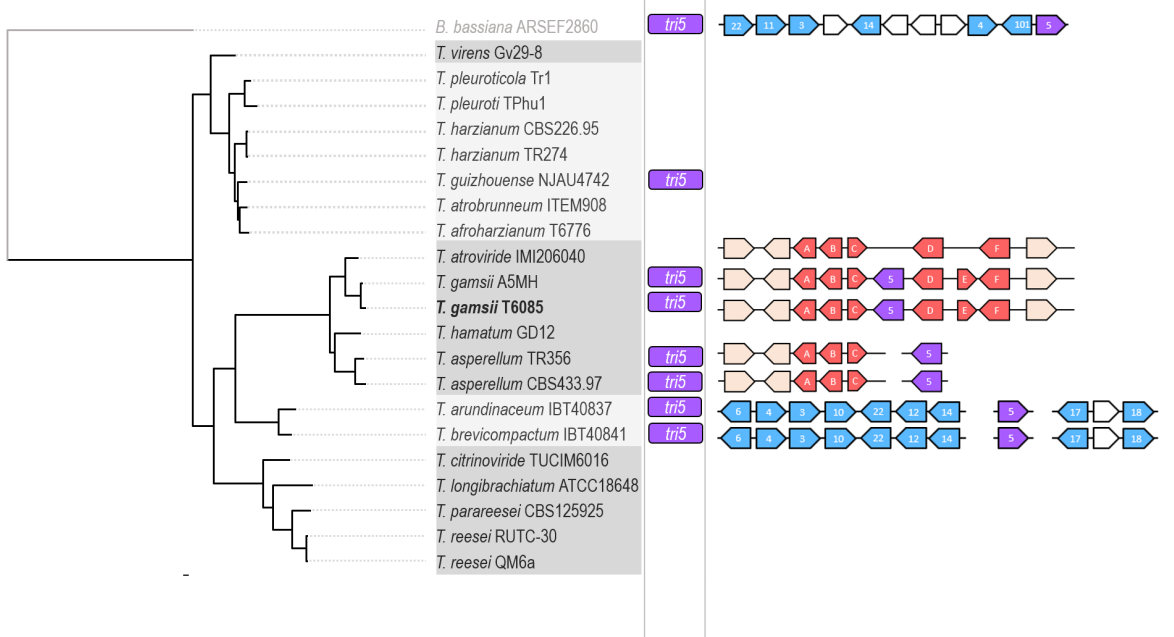

Figure 2. Trichodiene synthases in Trichoderma spp. (a) Phylogenetic relations among trichodiene synthase (TRI5) proteins in Trichoderma spp. and multiple alignment of the active center of the proteins were obtained using MAFFT v7.450 [52] and FasTree v2.1.11 [81]. Aspartate-rich metal binding motifs are indicated with asterisks. (b) Biosynthetic gene cluster containing tri5 and putative functions of the enclosing genes found in strains of T. gamsii. (c) Phylogenetic distribution of tri5 and their associated biosynthetic gene clusters in Trichoderma spp. Phylogenetic relations of Trichoderma spp. were obtained using MAFFT v7.450 [52] and FasTree v2.1.11 [81], using concatenated alignment of actin, calmodulin and transcription elongation factor-1 genes. Phylogenetic clades, according to Kubicek et al. (2019) [30], are shown in two different grey colors. Genes belonging to variants of the TRI loci reported in species of the clade Brevicompactum and B. bassiana, respectively, are shown in light blue. Genes found associated to tri5 (in purple) in T. gamsii are shown in red. 
Pairwise alignments of each TRI5 protein with that of T. arundinaceum and T. brevicompactum showed $77 \%$ of amino-acid identity in T. guizhouense, $80-82 \%$ in T. asperellum, respectively, and $87 \%$ in T. gamsii.

Assessment of the genomic context of tri5 genes by antiSMASH 5.0 [93] revealed this gene is included in a $21.2 \mathrm{~kb}$ cluster in T. gamsii, enclosing another six genes that were named as $A, B, C, D$, $E$, and $F$ (Figure $2 b$ ). Characterization based on conserved domains and similarity with characterized proteins in other systems enabled the identification of one regulatory protein, Zn2-C6 transcription factor $(\mathrm{TF})(A)$; four tailoring enzymes: oxygenase $(B)$, alpha-beta hydrolase $(C)$, oxygenase $(D)$, and carbonic anhydrase $(F)$; and one efflux transporter, Major Facilitator Superfamily (MFS) transporter $(E)$.

Alignment of these proteins with the TRI (trichothecene) proteins functionally associated to tri5 in the trichothecene-producer species of the Brevicompactum clade showed no sequence similarity. Furthermore, the genome of $T$. gamsii lacks the entire set of genes encoding the TRI proteins, with the exception of a distant related homolog of the gene tri101, which has already been reported in other Trichoderma species [43].

In order to search for homologous proteins in the Trichoderma genomes here explored, we used the protein sequences encoded in the cluster found in T. gamsii as queries in BLASTp analyses. Genes $A$, $B$ and $C$ were also found in all the other Trichoderma spp. belonging to the Viride clade, with conserved synteny (Figure 2c), and preliminary BLAST analyses suggest that these genes may be originated by horizontal gene transfer (HGT) from a donor belonging to the Eurotiomycetes. In any case, further analyses are needed in order to better understand the evolutionary origins of these genes. Instead, genes $D$ and $F$ are present in some of the genomes analyzed in closely-related species; while gene $E$ seems to be specific to $T$. gamsii.

These findings suggest the origin of a novel tri5-associated cluster in T. gamsii, which is likely involved in the biosynthesis of trichodiene derivates with unknown functions. According to this, tri5 could participate in two different sesquiterpene biosynthetic pathways in Trichoderma.

\subsection{Functional Differentiation of TS Family Members as the Driver for the High Genomic Potential for Terpenoid Biosynthesis in Trichoderma}

We identified 16 TS-encoding genes in the genome of Tgam (Table 1). For gene expression studies, we focused on nine genes encoding Class I TSs- $t s 1, t s 3, t s 4, t s 5, t s 6, t s 7, t s 9, t s 11$, and tri5-which represented a highly diverse functional group, well distributed across Trichoderma spp., according to our analyses. Thus, we excluded genes encoding Class II proteins and those involved in the biosynthesis of terpene precursors and protein prenylation.

We firstly investigated changes on TSs expression in 4-day-old liquid cultures of the fungus grown in modified MM (Figure 3a). The availability of $C$ source had contrasting effects on TS gene expression. The addition of $0.9 \%$ sucrose did not change the transcript levels of $t s 6$ and $t s 11$. Nevertheless, ts3 was significantly down-regulated (0.1-fold), whereas an up-regulation was observed in $t s 1, t s 9$ and particularly, in $t s 4$ (18.7-fold). In the same way, the addition of $0.5 \mathrm{mM} \mathrm{H}_{2} \mathrm{O}_{2}$ induced the opposite changes on gene expression, indicating that regulation of TS genes occurs in different manners in response to oxidative stress. While the expression of $t s 1$ and $t s 11$ did not change, $t s 3$ and $t s 6$ were down-regulated (0.3-, 0.6-fold, respectively). In contrast, ts9, encoding a putative indole diTS, was up-regulated (2.7-fold), suggesting that biosynthesis of indole diterpenes might occur in response to oxidative stress in Tgam. We observed that $\mathrm{N}$ starvation tended to negatively regulate TS genes, although significant differences were only found in $t s 3$ and $t s 11$ (0.4-fold). Similarly, the addition of $200 \mathrm{mM} \mathrm{NaCl}$ down-regulated the expression of TS genes (0.02-0.33-fold), with the exception of $t s 1$, whose expression was not affected. We did not detect transcripts of tri5, ts 5 or $t s 7$ in any of the conditions tested. 
a)

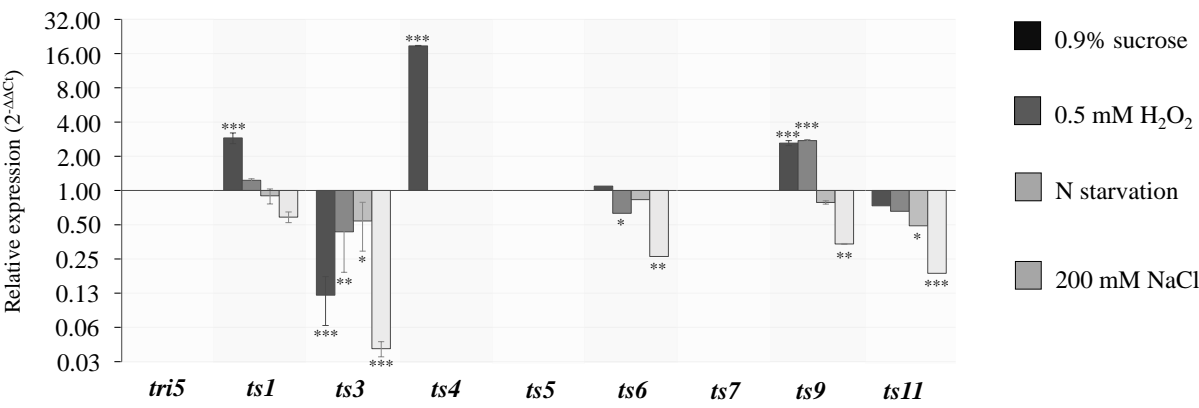

b)
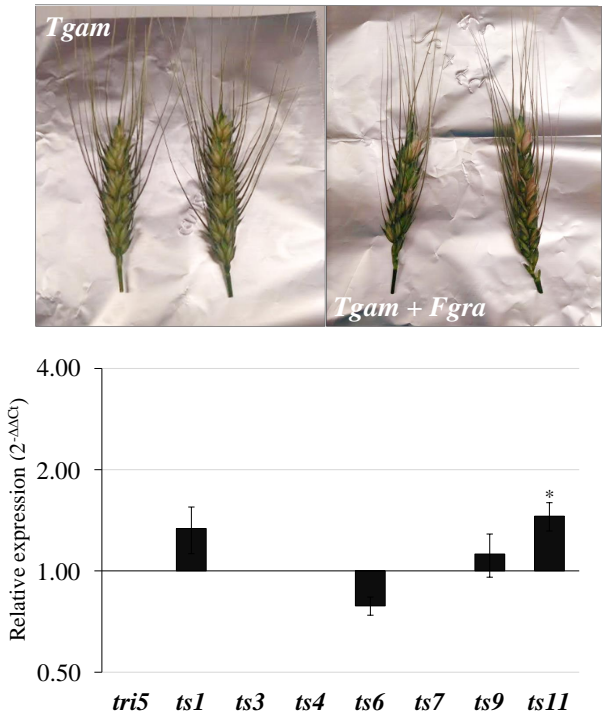

c)
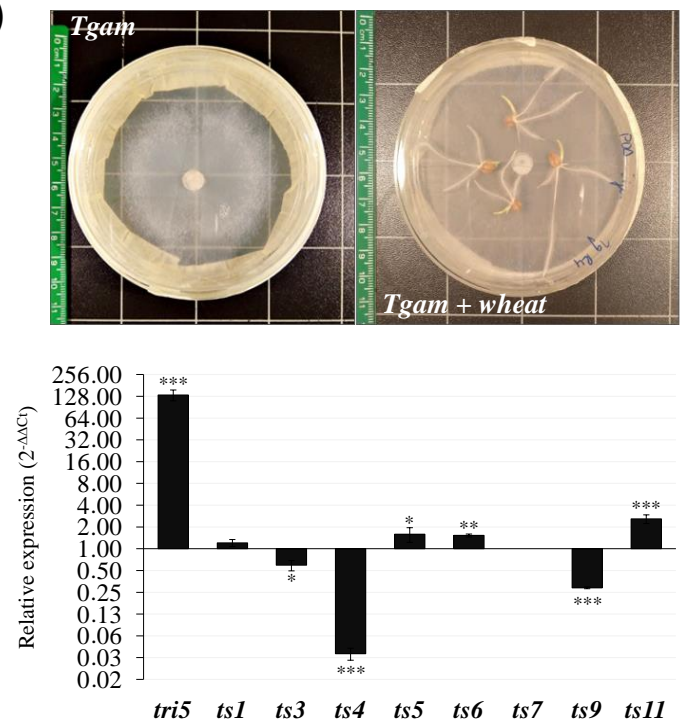

Figure 3. Gene expression studies of terpene synthase genes in T. gamsii T6085 in different environment conditions. (a) Liquid cultures of T. gamsii T6085 (Tgam) in different substrates. Total RNA was extracted from 4-day-old mycelium of Tgam grown on minimal medium without sucrose (MM) (basal condition, $2^{-\Delta \Delta \mathrm{Ct}}=1$ ), or MM with $0.9 \%$ sucrose, $\mathrm{MM} 0.5 \mathrm{mM} \mathrm{H}_{2} \mathrm{O}_{2}, \mathrm{MM}$ with only $0.01 \%$ of nitrogen ( $\mathrm{N}$ starvation), or $200 \mathrm{mM} \mathrm{NaCl}$, respectively. Grey color bars represent relative expression values of TS genes on each condition. (b) Interaction of Tgam with F. graminearum (Fgra) on wheat spikes. Total RNA was extracted from wheat spikes colonized by Tgam alone (basal condition, $2^{-\Delta \Delta \mathrm{Ct}}=1$ ) or by Tgam + Fgra, 6 days after inoculation of the pathogen. (c) Interaction of Tgam with wheat roots. Total RNA was extracted from mycelium of Tgam grown on PDA for 3 days (basal condition, $2^{-\Delta \Delta C t}=1$ ) and from wheat roots colonized by Tgam for 3 days. The $\beta$-tubulin gene was used as control for data normalization. Values are means of three independent biological replicates with the corresponding standard deviation. Fold change in sample relative to control is expressed as $2^{-\Delta \Delta C t}$. Statistically significant values are indicated with asterisks $\left(p \geq 0.05\right.$ no significative; $\left.0.05>p \geq 0.01={ }^{*} ; 0.01>p \geq 0.001={ }^{* *} ; p<0.001={ }^{* * *}\right)$.

Further, we investigated whether a differential expression of TS genes of Tgam takes place in the presence of Fgra on wheat spikes, where a reduction of FHB symptoms was observed (57.9 $\pm 4.7 \%$ DS) compared to Fgra alone plants $(88.3 \pm 1.2 \%$ DS) (Figure 3b). Analysis revealed that $t s 1, t s 6, t s 9$, and $t s 11$ were active when Tgam was on wheat spikes, regardless of the presence/absence of the pathogen. Expression of $t s 1, t s 6$ and $t s 9$ did not change significantly between the two conditions, indicating that these genes are not particularly involved in this triple interaction. Instead, ts11 was slightly up-regulated (1.45-fold) when Tgam was on spikes with Fgra, suggesting the presence of the pathogen could directly induce changes in its expression or could mediate physiological changes in spikes that promoted changes on ts11 expression. These results indicate that Tgam did not induce 
prominent changes in terpene biosynthesis when interacting with Fgra on wheat spikes, under the conditions tested.

Finally, we observed that root colonization affected TSs expression in Tgam, which differentially regulated most of its TS genes, with the exception of $t s 7$, whose transcripts were not detected in any condition, and $t s 1$, in which expression did not change (Figure 3c). This clearly indicates a reprogramming in terpene biosynthesis in Tgam when colonizing wheat roots. In particular, a modulation in sesquiterpene biosynthesis occurred in Tgam during root colonization. Whereas ts5 was slightly up-regulated (1.58-fold), the contact with the roots strongly repressed the expression of ts4 (0.03-fold) and to a lesser extent that of ts3 (0.59-fold). Nevertheless, the most remarkable difference was found in the expression of tri5, which was 134-fold up-regulated when the fungus was on the roots, suggesting that signals from the roots are responsible for triggering the expression of this gene in Tgam. In addition, the interaction with the roots up-regulated ts6 (1.52-fold) and ts11 (2.58-fold). Since ts6 was predicted to encode an SQS, this suggests that triterpene biosynthesis was slightly enhanced in Tgam when colonizing the wheat roots. Interestingly, $t s 9$ was found highly down-regulated ( 0.28 -fold), thus suggesting a repression of indole diterpene biosynthesis in the fungus during the interaction with wheat roots.

\section{Discussion}

The impressive number of TSs we found in the genomes analyzed demonstrate that terpenoid biosynthesis has a great impact on the diversity and complexity of SMs in Trichoderma. Indeed, the TS-gene inventory of these species (15-23 genes per genome) clearly outnumbers those found in other fungi considered as rich producers of SMs, such as Aspergillus spp. (2-10 genes per genome) [30,94]. This reflects the importance of TSs and terpenoids in the ecology of Trichoderma. However, most of the Trichoderma TSs have not yet been characterized [30], and available information about the diversity of TSs in Trichoderma is scarce. Thus, we focused on characterizing the TS-gene arsenal of this genus, providing a complete overview of the nature and diversity of the Trichoderma terpenoid biosynthetic inventory.

Although TS family size is very homogeneous within Trichoderma, we were able to identify cladespecific TSs, which reflect particular portions of the terpenoid inventory shared by phylogenetically close species. Thus, despite their similar terpenoid biosynthetic potential, the species of Trichoderma have adapted their terpene production according to different environmental demands. Species of Viride clade constitute an example, as they are missing in some groups of TSs that are present in the other clades, although they have evolved specific TSs, which are absent in other species of the genus.

According to our results, Trichoderma spp. have a huge potential for sesquiterpene biosynthesis. We identified eight groups of sesquiTSs, which constitute almost a third of the total number of TSs found in this work. Species of Viride are particularly rich in sesquiTS belonging to the TRI5-superfamily, and they also contain HAD-like TSs, which are absent in species of other clades. These HAD-like proteins harbor a DxDTT motif, which is a variant of the DxDD found in Class II diTS [95,96]. Shinohara et al. [97] reported that some sesquiTS can contain HAD-like domains and DxDTT motifs, leading to FPP cyclization through a protonation step, instead of by an ionization step. We hypothesized that HAD-like TSs might be particular bifunctional sesquiTS, synthesizing specific metabolites of Viride clade.

Previous studies reported that some Trichoderma spp. have the potential to synthesize longiborneol [19], an intermediate of the culmorin biosynthetic pathway $[19,56]$. According to our results, longiborneol biosynthesis is very widespread in Trichoderma, but is absent in species of the Viride clade. Since culmorin production has not been reported in Trichoderma, longiborneol could be synthesized as a sole compound or as an intermediate of unknown biosynthetic pathways in these species. Most of these proteins show a conserved $\mathrm{D}(\mathrm{D} / \mathrm{E}) \mathrm{HFD}$ motif, which is partially conserved (NDHFD) in proteins of T. arundinaceum and T. brevicompactum. Site-directed mutagenesis and crystallography studies on TSs have revealed that the first aspartate residue (D) of the metal-binding motif interacts directly with $\mathrm{Mg}^{2+}$ [98], and its replacement can lead to anomalous cyclization products or a product mixture [99]. According to this, 
longiborneol synthases of Brevicompactum species could be actually involved in terpenoid blend formation or in the biosynthesis of newly terpenoids.

We found that most Trichoderma spp. can potentially produce presilphiperfolan- $8 \beta$-ol. This compound is thought to play a central role in the biosynthesis of a wide range of polycyclic sesquiterpenes in fungi [73]. Thus, these TSs may contribute to generating a variety of structurally complex terpenoids in Trichoderma. Proteins sharing similarity with fungal pentalenene synthases were also identified, which are involved in the biosynthesis of the parent hydrocarbon of the pentalenolactone family of fungal antibiotics [100]. Nevertheless, the variability found on the structure of the active center of these proteins suggests that some of them probably synthesize sesquiterpenoids others than pentalenene.

Our analyses revealed that single-copy SQS and OSC enzymes provide the linear and cyclic precursors required for triterpene biosynthesis in most Trichoderma species. However, the presence of additional SQSs indicates that pathway-specific SQSs could be present as well. In the same way, additional GGPP and FPP synthases may act as donors of terpenoid precursors in specific biosynthetic pathways in members of the clades Harzianum and Brevicompactum. This most likely reflects specific portions of the terpenoid inventory of these species and guarantees an efficient distribution of terpenoid precursors between primary and secondary metabolism.

Harziandione was the first diterpene isolated from Trichoderma spp. [101], and a number of these compounds have been recently reported in these species [102-106]. Nevertheless, the low number of diTS found here indicates that the ability of Trichoderma spp. for diterpene biosynthesis is scarce and not very widespread within the genus.

Interestingly, our analyses revealed that Trichoderma spp. have the potential to produce sesterterpenes and indole diterpenes. Sesterterpenes are rare among terpenoids, and their antimicrobial and nematocidal properties [107] could confer competitive advantages to some Trichoderma spp. On the other hand, the production of indole diterpenes has been reported in some Sordariomycetes, being involved in protecting their reproductive structures from fungivores [108]. Many of the indole diterpene-producer fungi establish symbiotic relations with plants, thus, biosynthesis of these compounds may confer ecological advantages on Trichoderma-host associations as well [109].

No monoTS were found among the genomes analysed in this work, although production of monoterpenes has been reported in T. virens $[27,110]$. No bona fide monoTS have been identified in fungi [111], and the scarce availability of sequences of these enzymes could have led to miss-predict them. Since fungal sesquiTS are able to cyclize GPP [112], we hypothesize that monoTSs of Trichoderma could be actually included within "uncharacterized group 4", since they are phylogenetically close to sesquiTS, and other uncharacterized proteins were found restricted to some clades not including T. virens or fell into the TRI5 superfamily.

We found highly conserved tri5 orthologs in non-trichothecene-producer Trichoderma species missing on the entire TRI cluster, some of which have been previously reported [113]. This leaves open some questions about the role of tri5 in beneficious Trichoderma spp., a non-producer of trichothecenes. Unlike other tri5-containing species, tri5 is embedded in a BGC in T. gamsii, enclosing tailoring enzymes, a TF and a transporter. The presence of a TF within the cluster suggests a pathway-specific regulation, while the presence of a transporter suggests the production of a sesquiterpenoid with extra-cellular functions. Some of these genes were likely transferred to Trichoderma spp. by HGT from Eurotiomycetes, but the entire cluster is only present in T. gamsii, suggesting the origin of a novel tri5-associated BGC in this species. This cluster could lead to an uncharted trichodiene-derived sesquiterpenic biosynthetic pathway, producing novel metabolites with potential agronomic interest. Since tri5 seems to be functionally associated to two different BGCs (TRI and that found in T. gamsii), we hypothesize this sesquiTS is involved in different metabolic pathways in Trichoderma.

The striking genomic potential for terpenoid production of Trichoderma spp. found in this work suggests that functional differentiation of gene family members is the driver for the high TS gene numbers of these species. Here we provide a picture showing that different TS genes are differentially regulated, a strong indication of different biological functions. 
Availability of $C$ source had contrasting effects on the expression of TS genes, as observed in SMs genes from other fungi [57,114]. Similarly, TS genes were regulated in opposite ways in response to oxidative stress. Association of oxidative stress with SMs biosynthesis in fungi has been extensively demonstrated, and it has been suggested that it is induced to prevent fungi from ROS damage [115]. In particular, up-regulation of $t s 9$ suggests that biosynthesis of indole diterpenes might occur in T. gamsii T6085 under oxidative stress conditions, as it has been observed in Aspergillus spp. [116]. Interestingly, the addition of $0.9 \%$ sucrose or $0.5 \mathrm{mM} \mathrm{H}_{2} \mathrm{O}_{2}$ to the medium did not induce tri5 expression in T. gamsii T6085, unlike what has been observed in T. brevicompactum when grown in the presence of $1 \%$ or $2 \%$ sucrose or in the presence of $0.5 \mathrm{mM} \mathrm{H}_{2} \mathrm{O}_{2}$ [24]. This suggests different types of regulation of tri5 in T. gamsii T6085 and T. brevicompactum.

Nitrogen availability and saline stress have a considerable impact on fungal secondary metabolism [117-119]. N starvation and saline stresses negatively regulated TS genes in T. gamsii T6085, suggesting terpenoid biosynthesis does not confer particular advantages to the fungus to overcome these stresses.

In $T$. arundinaceum, tri gene expression is affected when grown in dual cultures with B. cinerea, while polyketides and harzianum A (HA) produced by the first induce changes in some $B$. cinerea genes linked to its virulence [23]. Since T. gamsii T6085 is able to suppress F. graminearum on wheat spikes and to reduce DON production by the pathogen [31,32,34,35], we investigated whether a differential expression of TS genes of T. gamsii T6085 occurs when the fungus interacts with $F$. graminearum on wheat spikes. However, our results show that the presence of the pathogen did not induce prominent changes in TS expression in T. gamsii T6085 when both fungi were on wheat spikes, although ts 11 was found slightly up-regulated. Gene expression patterns are highly dynamic, and more extensive time-course experiments are needed to provide more information about the role of TSs in this scenario.

Root colonization by Trichoderma is an intimate relationship involving a tightly regulated exchange of molecular signals including SMs [120]. When Trichoderma colonizes the roots, it releases a variety of SMs that promote substantial changes in plant biochemistry, which in turn, cause changes in the fungal physiology [8]. Our results indicate that a significative reprogramming of terpene biosynthesis occurs in T. gamsii T6085 when it colonizes wheat roots. Down-regulation of ts 9 suggests that root colonization induces a repression in indole diterpene biosynthesis in the fungus. In addition, the contrasting effects observed in the expression of sesquiTS and the up-regulation of the SQS suggest that root colonization induces a modulation on sesquiterpene and triterpene biosynthesis in T. gamsii T6085 through FPP as the central node. The absence of tri5 expression in response to wheat spikes and the strong up-regulation observed during root colonization was remarkable, as it suggests that signals from the roots induce the expression of this gene in T. gamsii T6085. Although activation of tri5 usually leads to the production of phytotoxic compounds, such as trichodermin in T. brevicompactum [24], HA produced by T. arundinaceum lacks phytotoxic activity and has a crucial role in plant protection against $B$. cinerea [21]. This example illustrates how different ecological demands led to an adjustment in metabolic pathways governed by a single gene signature in species within the same fungal genus [28]. In this context, we can imagine the involvement of tri5 in the biosynthesis of a sesquiterpenoid related to the promotion of beneficial relationships between T. gamsii T6085 and wheat plants, a question that must be further addressed by using tri5-deletion mutants of the fungus. Results strongly indicate the involvement of TS genes in the interaction of T. gamsii T6085 with plant roots, and further studies determining their impact on the plant physiology will provide further information about the roles of these genes in the Trichoderma-plant interaction.

Supplementary Materials: The following are available online at http://www.mdpi.com/2076-2607/8/10/1603/s1, Figure S1: Phylogenetics of terpene synthase proteins in Trichoderma spp., Table S1: Trichoderma spp. and Beauveria bassiana genomic platform, Table S2: Terpene synthase proteins functionally characterized in filamentous fungi, Table S3: Primer sequences used for gene expression analysis ( $5^{\prime}$ to $\left.3^{\prime}\right)$, Table S4: TS-gene content per each Trichoderma spp. 
Author Contributions: G.V., E.M., S.S., R.H. and R.B. (Riccardo Baroncelli) designed the research. I.V., R.B. (Riccardo Baroncelli), M.E.M-D., R.B. (Rodolfo Bernardi) and G.P. designed and performed the experiments. I.V., S.S., R.B. (Riccardo Baroncelli), R.B. (Rodolfo Bernardi), and M.E.M.-D. analysed the data, and G.V., E.M. and R.H. contributed to data interpretation. I.V. wrote the manuscript, and all the authors contributed to its revision. All authors have read and agreed to the published version of the manuscript.

Funding: This research was funded by the "University of Pisa (Italy) PhD projects" and the "Junta de Castilla y León (Spain) SA270P18 and CLU-2018-04 projects". The research by M.E. M-D and R. Baroncelli was founded by the Program II of Postdoctoral Fellows of the University of Salamanca.

Conflicts of Interest: The authors declare no conflict of interest. The funders had no role in the design of the study; in the collection, analyses, or interpretation of data; in the writing of the manuscript, or in the decision to publish the results.

\section{References}

1. Harman, G.E.; Howell, C.R.; Viterbo, A.; Chet, I.; Lorito, M. Trichoderma species opportunistic, avirulent plant symbionts. Nat. Rev. Microbiol. 2004, 84, 377-393. [CrossRef]

2. Fiorini, L.; Guglielminetti, L.; Mariotti, L.; Curadi, M.; Picciarelli, P.; Scartazza, A.; Sarrocco, S.; Vannacci, G. Trichoderma harzianum T6776 modulates a complex metabolic network to stimulate tomato cv. Micro-Tom growth. Plant Soil 2016, 400, 351-366. [CrossRef]

3. Shoresh, M.; Harman, G.E.; Mastouri, F. Induced systemic resistance and plant responses to fungal biocontrol agents. Annu. Rev. Phytopathol. 2010, 48, 21-43. [CrossRef]

4. Lorito, M.; Farkas, V.; Rebuffat, S.; Bodo, B.; Kubicek, C.P. Cell wall synthesis is a major target of mycoparasitic antagonism by Trichoderma harzianum. J. Bacteriol. 1996, 178, 6382-6385. [CrossRef]

5. Vinale, F.; Sivasithamparam, K.; Ghisalberti, E.L.; Marra, R.; Barbetti, M.J.; Li, H.; Woo, S.L.; Lorito, M. A novel role for Trichoderma secondary metabolites in the interactions with plants. Physiol. Mol. Plant Pathol. 2008, 72, 80-86. [CrossRef]

6. Viterbo, A.; Wiest, A.; Brotman, Y.; Chiet, I.; Kenerley, C. The 18 mer peptaibols from Trichoderma virens elicit plant defence responses. Mol. Plant Pathol. 2007, 8, 737-746. [CrossRef]

7. Contreras-Cornejo, H.A.; Macías-Rodríguez, L.; del-Val, E.; Larsen, J. Ecological functions of Trichoderma spp. and their secondary metabolites in the rhizosphere: Interactions with plants. FEMS Microbiol. Ecol. 2016, 92, fiw036. [CrossRef]

8. Contreras-Cornejo, H.A.; Del-Val, E.; Macías-Rodríguez, L.; Alarcón, A.; González-Esquivel, C.E.; Larsen, J. Trichoderma atroviride, a maize root associated fungus, increases the parasitism rate of the fall armyworm Spodoptera frugiperda by its natural enemy Campoletis son. Soil Biol. Biochem. 2018, 122, 196-202. [CrossRef]

9. Hermosa, R.; Cardoza, R.E.; Rubio, M.B.; Gutiérrez, S.; Monte, E. Secondary metabolism and antimicrobial metabolites of Trichoderma. In Biotechnology and Biology of Trichoderma; Vijai, G.P., Schmoll, M., Herrera-Estrella, A., Upadhyay, R.S., Druzhinina, I., Tuohy, M.G., Eds.; Elsevier: Amsterdam, The Netherlands, 2014; pp. 125-137.

10. Patil, A.S.; Patil, S.R.; Paikrao, H.M. Trichoderma secondary metabolites: Their biochemistry and possible role in disease management. In Microbial-Mediated Induced Systemic Resistance in Plants; Choudhary, D.K., Varma, A., Eds.; Springer: Singapore, 2016; pp. 69-102.

11. Rai, S.; Solanki, M.K.; Solanki, A.C.; Surapathrudu, K. Biocontrol potential of Trichoderma spp.: Current understandings and future outlooks on molecular techniques. In Plant Health Under Biotic Stress; Ansari, R.A., Mahmood, I., Eds.; Springer: Singapore, 2019; pp. 129-160.

12. Salwan, R.; Rialch, N.; Sharma, V. Bioactive volatile metabolites of Trichoderma: An overview. In Secondary Metabolites of Plant Growth Promoting Rhizomicroorganisms; Singh, H.B., Keswani, C., Reddy, M.S., Sansinenea, E., García-Estrada, C., Eds.; Springer: Singapore, 2019; pp. 87-111.

13. Yu, J.H.; Keller, N. Regulation of secondary metabolism in filamentous fungi. Annu. Rev. Phytopathol. 2005, 43, 437-458. [CrossRef] [PubMed]

14. Reino, J.L.; Guerrero, R.F.; Hernandez-Galan, R.; Collado, I.G. Secondary metabolites from species of the biocontrol agent Trichoderma. Phytochem. Rev. 2008, 7, 89-123. [CrossRef]

15. Pachauri, S.; Sherkhane, P.D.; Mukherjee, P. Secondary metabolism in Trichoderma: Chemo- and genodiversity. In Microbial Diversity in Ecosystem Sustainability; Satyanarayana, T., Das, S.K., Johri, B.N., Eds.; Springer: Singapore, 2019; pp. 441-456. 
16. Zeilinger, S.; Gruber, S.; Bansal, R.; Mukherjee, P.K. Secondary metabolism in Trichoderma—Chemistry meets genomics. Fungal Biol. Rev. 2016, 30, 74-90. [CrossRef]

17. Quin, M.B.; Flynn, C.M.; Schmidt-Dannert, C. Traversing the fungal terpenome. Nat. Prod. Rep. 2014, 31, 1449-1473. [CrossRef] [PubMed]

18. Guzmán-Chávez, F.; Zwahlen, R.D.; Bovenberg, R.A.L.; Driessen, A.J.M. Engineering of the filamentous fungus Penicillium chrysogenum as cell factory for natural products. Front. Microbiol. 2018, 9, 2768. [CrossRef] [PubMed]

19. Bansal, R.; Mukherjee, P.K. The terpenoid biosynthesis toolkit of Trichoderma. Nat. Prod. Commun. $2016,11$. [CrossRef]

20. Cardoza, R.E.; Malmierca, M.G.; Hermosa, M.R.; Alexander, N.J.; McCormick, S.P.; Proctor, R.H.; Tijerino, A.M.; Rumbero, A.; Monte, E.; Gutiérrez, S. Identification of loci and functional characterization of trichothecene biosynthesis genes in filamentous fungi of the genus Trichoderma. Appl. Environ. Microbiol. 2011, 77, 4867-4877. [CrossRef]

21. Malmierca, M.G.; Cardoza, R.E.; Alexander, N.J.; McCormick, S.P.; Collado, I.G.; Hermosa, R.; Monte, E.; Gutiérrez, S. Relevance of trichothecenes in fungal physiology: Disruption of tri5 in Trichoderma arundinaceum. Fungal Genet. Biol. 2013, 53, 22-33. [CrossRef]

22. Malmierca, M.G.; McCormick, S.P.; Cardoza, R.E.; Alexander, N.J.; Monte, E.; Gutiérrez, S. Production of trichodiene by Trichoderma harzianum alters the perception of this biocontrol strain by plants and antagonized fungi. Environ. Microbiol. 2014, 17, 2628-2646. [CrossRef]

23. Malmierca, M.G.; Barua, J.; McCormick, S.P.; Izquierdo-Bueno, I.; Cardoza, R.E.; Alexander, N.J.; Hermosa, R.; Collado, I.G.; Monte, E.; Gutiérrez, S. Novel aspinolide production by Trichoderma arundinaceum with a potential role in Botrytis cinerea antagonistic activity and plant defence priming. Environ. Microbiol. 2015, 17, 1103-1118. [CrossRef]

24. Tijerino, A.; Cardoza, R.E.; Moraga, J.; Malmierca, M.G.; Vicente, F.; Aleu, J.; Collado, I.G.; Gutiérrez, S.; Monte, E.; Hermosa, R. Overexpression of the trichodiene synthase gene tri5 increases trichodermin production and antimicrobial activity in Trichoderma Brevicompactum. Fungal Genet. Biol. 2011, 48, 285-296. [CrossRef]

25. Tijerino, A.; Hermosa, R.; Cardoza, R.E.; Moraga, J.; Malmierca, M.G.; Aleu, J.; Collado, I.G.; Monte, E.; Gutierrez, S. Overexpression of the Trichoderma brevicompactum tri5 gene: Effect on the expression of the trichodermin biosynthetic genes and on tomato seedlings. Toxins 2011, 3, 1220-1232. [CrossRef]

26. Piłsyk, S.; Perlińska-Lenart, U.; Górka-Nieć, W.; Graczyk, S.; Antosiewicz, B.; Zembek, P.; Palamarczyk, G.; Kruszewska, J.S. Overexpression of erg20 gene encoding farnesyl pyrophosphate synthase has contrasting effects on activity of enzymes of the dolichyl and sterol branches of mevalonate pathway in Trichoderma reesei. Gene 2014, 544, 114-122. [CrossRef] [PubMed]

27. Crutcher, F.K.; Parich, A.; Schuhmacher, R.; Mukherjee, P.K.; Zeilinger, S.; Kenerley, C.M. A putative terpene cyclase, vir4, is responsible for the biosynthesis of volatile terpene compounds in the biocontrol fungus Trichoderma virens. Fungal Genet. Biol. 2013, 56, 67-77. [CrossRef]

28. Mukherjee, P.K.; Horwitz, B.A.; Herrera-Estrella, A.; Schmoll, M.; Kenerley, C.M. Trichoderma research in the genome era. Annu. Rev. Phytopathol. 2013, 51, 105-129. [CrossRef] [PubMed]

29. Kubicek, C.P.; Herrera-Estrella, A.; Seidl-Seiboth, V.; Martinez, D.A.; Druzhinina, I.S.; Thon, M.; Zeilinger, S.; Casas-Flores, S.; Horwitz, B.A.; Mukherjee, P.K.; et al. Comparative genome sequence analysis underscores mycoparasitism as the ancestral lifestyle of Trichoderma. Genome Biol. 2011, 12, R40. [CrossRef] [PubMed]

30. Kubicek, C.P.; Steindorff, A.S.; Chenthamara, K.; Manganiello, G.; Henrissat, B.; Zhang, J.; Cai, F.; Kopchinskiy, A.G.; Kubicek, E.M.; Kuo, A.; et al. Evolution and comparative genomics of the most common Trichoderma species. BMC Genom. 2019, 20, 485. [CrossRef]

31. Sarrocco, S.; Mauro, A.; Battilani, P. Use of competitive filamentous fungi as an alternative approach for mycotoxin risk reduction in staple cereals: State of art and future perspectives. Toxins 2019, 11, 701. [CrossRef] [PubMed]

32. Sarrocco, S.; Moncini, L.; Pachetti, G.; Moretti, A.; Ritieni, A.; Vannacci, G. Biological control of Fusarium Head Blight under field conditions. Biocontrol Plant Pathog. Sustain. Agric. 2013, 86, 95-100.

33. Matarese, F. Biocontrol of Fusarium head bligth: Molecular interactions between Trichoderma and mycotoxigenic Fusarium. Ph.D. Thesis, University of Pisa, Pisa, Italy, 2010. 
34. Matarese, F.; Sarrocco, S.; Gruber, S.; Seidl-Seiboth, V.; Vannacci, G. Biocontrol of Fusarium head blight: Interactions between Trichoderma and mycotoxigenic Fusarium. Microbiol. 2012, 158, 98-106. [CrossRef]

35. Sarrocco, S.; Matarese, F.; Moncini, L.; Pachetti, G.; Ritieni, A.; Moretti, A.; Vannacci, G. Biocontrol of Fusarium head blight by spike application of Trichoderma gamsii. J. Plant Pathol. 2013, S1, 19-27.

36. Sarrocco, S.; Esteban, P.; Vicente, I.; Bernardi, R.; Plainchamp, T.; Domenichini, S.; Puntoni, G.; Baroncelli, R.; Vannacci, G.; Dufresne, M. Straw competition and wheat root endophytism of Trichoderma gamsii T6085 as useful traits in the biocontrol of Fusarium head blight. Phytopathology 2020, submitted.

37. National Center for Biotechnology (NCBI). Available online: http://ncbi.nlm.nih.gov (accessed on 17 October 2020).

38. Joint Genome Institute (JGI). Available online: http://mycocosm.jgi.doe.gov/mycocosm/home (accessed on 17 October 2020).

39. Xiao, G.; Ying, S.H.; Zheng, P.; Wang, Z.L.; Zhang, S.; Xie, X.Q.; Shang, Y.; St. Leger, R.J.; Zhao, G.-P.; Wang, C.; et al. Genomic perspectives on the evolution of fungal entomopathogenicity in Beauveria Bassiana. Sci. Rep. 2012, 2, 483. [CrossRef] [PubMed]

40. Druzhinina, I.S.; Chenthamara, K.; Zhang, J.; Atanasova, L.; Yang, D.; Miao, Y.; Rahimi, M.J.; Grujic, M.; Cai, F.; Pourmehdi, S.; et al. Massive lateral transfer of genes encoding plant cell wall-degrading enzymes to the mycoparasitic fungus Trichoderma from its plant-associated hosts. PLoS Genet. 2018, 14, e1007322. [CrossRef]

41. Studholme, D.J.; Harris, B.; Le Cocq, K.; Winsbury, R.; Perera, V.; Ryder, L.; Ward, J.L.; Beale, M.H.; Thornton, C.R.; Grant, M. Investigating the beneficial traits of Trichoderma hamatum GD12 for sustainable agriculture-insights from genomics. Front. Plant Sci. 2013, 4, 258. [CrossRef] [PubMed]

42. Baroncelli, R.; Zapparata, A.; Piaggeschi, G.; Sarrocco, S.; Vannacci, G. Draft Whole-genome sequence of Trichoderma gamsii T6085, a promising biocontrol agent of Fusarium head blight on wheat. Genome Announc. 2016, 4, e01747-15. [CrossRef] [PubMed]

43. Proctor, R.H.; McCormick, S.P.; Kim, H.S.; Cardoza, R.E.; Stanley, A.M.; Lindo, L.; Kelly, A.; Brown, D.W.; Lee, T.; Vaughan, M.M.; et al. Evolution of structural diversity of trichothecenes, a family of toxins produced by plant pathogenic and entomopathogenic fungi. PLoS Pathog. 2018, 14, e1006946. [CrossRef]

44. Yang, D.; Pomraning, K.; Kopchinskiy, A.; Aghcheh, R.K.; Atanasova, L.; Chenthamara, K.; Baker, S.E.; Zhang, R.; Shen, Q.; Freitag, M.; et al. Genome sequence and annotation of Trichoderma parareesei, the ancestor of the cellulase producer Trichoderma reesei. Genome Announc. 2015, 3, e00885-15. [CrossRef]

45. Li, W.C.; Huang, C.H.; Chen, C.L.; Chuang, Y.C.; Tung, S.Y.; Wang, T.F. Trichoderma reesei complete genome sequence, repeat-induced point mutation, and partitioning of CAZyme gene clusters. Biotechnol. Biofuels 2017, 10, 170. [CrossRef]

46. Jourdier, E.; Baudry, L.; Poggi-Parodi, D.; Vicq, Y.; Koszul, R.; Margeot, A.; Marbouty, M.; Bidard, F. Proximity ligation scaffolding and comparison of two Trichoderma reesei strains genomes. Biotechnol. Biofuels 2017, 10, 151. [CrossRef]

47. Marik, T.; Urbán, P.; Tyagi, C.; Szekeres, A.; Leitgeb, B.; Vágvölgyi, M.; Manczinger, L.; Druzhinina, I.S.; Vágvölgyi, C.; Kredics, L. Diversity profile and dynamics of peptaibols produced by green mould Trichoderma species in interactions with their hosts Agaricus bisporus and Pleurotus ostreatus. Chem. Biodivers. 2017, 14, e1700033. [CrossRef]

48. Baroncelli, R.; Piaggeschi, G.; Fiorini, L.; Bertolini, E.; Zapparata, A.; Pè, M.E.; Sarrocco, S.; Vannacci, G. Draft whole-genome sequence of the biocontrol agent Trichoderma harzianum T6776. Genome Announc. 2015, 3, e00647-15. [CrossRef]

49. Fanelli, F.; Liuzzi, V.C.; Logrieco, A.F.; Altomare, C. Genomic characterization of Trichoderma atrobrunneum (T. harzianum species complex) ITEM 908: Insight into the genetic endowment of a multi-target biocontrol strain. BMC Genom. 2018, 19, 662. [CrossRef] [PubMed]

50. Jones, P.; Binns, D.; Chang, H.Y.; Fraser, M.; Li, W.; McAnulla, C.; McWilliam, H.; Maslen, J.; Mitchell, A.; Nuka, G.; et al. InterProScan 5: Genome-scale protein function classification. Bioinformatics 2014, 30, 1236-1240. [CrossRef] [PubMed]

51. Gao, Y.; Honzatko, R.B.; Peters, R.J. Terpenoid synthase structures: A so far incomplete view of complex catalysis. Nat. Prod. Rep. 2012, 29, 1153. [CrossRef]

52. Katoh, K.; Standley, D.M. MAFFT Multiple Sequence Alignment Software Version 7: Improvements in performance and usability. Mol. Biol. Evol. 2013, 30, 772-780. [CrossRef] [PubMed] 
53. Tudzynski, B.; Kawaide, H.; Kamiya, Y. Gibberellin biosynthesis in Gibberella fujikuroi: Cloning and characterization of the copalyl diphosphate synthase gene. Curr. Genet. 1998, 34, 234-240. [CrossRef] [PubMed]

54. Linnemannstöns, P.; Prado, M.; Fernández-Martín, R.; Tudzynski, B.; Avalos, J. A carotenoid biosynthesis gene cluster in Fusarium fujikuroi: The genes carB and carA. Mol. Genet. Genom. 2002, 267, 593-602. [CrossRef] [PubMed]

55. Rynkiewicz, M.J.; Cane, D.E.; Christianson, D.W. Structure of trichodiene synthase from Fusarium sporotrichioides provides mechanistic inferences on the terpene cyclization cascade. Proc. Natl. Acad. Sci. USA 2001, 98, 13543-13548. [CrossRef]

56. McCormick, S.P.; Alexander, N.J.; Harris, L.J. CLM1 of Fusarium graminearum encodes a longiborneol synthase required for culmorin production. Appl. Environ. Microbiol. 2009, 76, 136-141. [CrossRef]

57. Jiao, F.; Kawakami, A.; Nakajima, T. Effects of different carbon sources on trichothecene production and Tri gene expression by Fusarium graminearum in liquid culture. FEMS Microbiol. Lett. 2008, 285, 212-219. [CrossRef]

58. Hon, T.M.; Desjardins, A.E. Isolation and gene disruption of the Tox 5 gene encoding trichodiene synthase in Gibberella pulicaris. Mol. Plant-Microbe Interact. 1992, 5, 249-256. [CrossRef]

59. Bomke, C.; Rojas, M.C.; Gong, F.; Hedden, P.; Tudzynski, B. Isolation and characterization of the gibberellin biosynthetic gene cluster in Sphaceloma manihoticola. Appl. Environ. Microbiol. 2008, 74, 5325-5339. [CrossRef]

60. Oikawa, H.; Toyomasu, T.; Toshima, H.; Ohashi, S.; Kawaide, H.; Kamiya, Y.; Ohtsuka, M.; Shinoda, S.; Mitsuhashi, W.; Sassa, T. Cloning and functional expression of cDNA encoding aphidicolan-16 $\beta$-ol synthase: A key enzyme responsible for formation of an unusual diterpene skeleton in biosynthesis of aphidicolin. J. Am. Chem. Soc. 2001, 123, 5154-5155. [CrossRef]

61. Toyomasu, T.; Tsukahara, M.; Kaneko, A.; Niida, R.; Mitsuhashi, W.; Dairi, T.; Kato, N.; Sassa, T. Fusicoccins are biosynthesized by an unusual chimera diterpene synthase in fungi. Proc. Natl. Acad. Sci. USA 2007, 104, 3084-3088. [CrossRef]

62. Chiba, R.; Minami, A.; Gomi, K.; Oikawa, H. Identification of ophiobolin F synthase by a genome mining approach: A sesterterpene synthase from Aspergillus clavatus. Org. Lett. 2013, 15, 594-597. [CrossRef] [PubMed]

63. Matsuda, Y.; Mitsuhashi, T.; Lee, S.; Hoshino, M.; Mori, T.; Okada, M.; Okada, M.; Zhang, H.; Hayashi, F.; Abe, I. Astellifadiene: Structure determination by NMR spectroscopy and crystalline sponge method, and elucidation of its biosynthesis. Angew. Chem. 2016, 128, 5879-5882. [CrossRef]

64. Okada, M.; Matsuda, Y.; Mitsuhashi, T.; Hoshino, S.; Mori, T.; Nakagawa, K.; Quan, Z.; Qin, B.; Zhang, H.; Hayashi, F.; et al. Genome-based discovery of an unprecedented cyclization mode in fungal sesterterpenoid biosynthesis. J. Am. Chem. Soc. 2016, 138, 10011-10018. [CrossRef]

65. Qin, B.; Matsuda, Y.; Mori, T.; Okada, M.; Quan, Z.; Mitsuhashi, T.; Wakimoto, T.; Abe, I. An unusual chimeric diterpene synthase from Emericella variecolor and its functional conversion into a sesterterpene synthase by domain swapping. Angew. Chem. 2015, 128, 1690-1693. [CrossRef]

66. Sishova, E.Y.; Di Costanzo, L.; Cane, D.E.; Christianson, D.W. X-ray crystal structure of aristolochene synthase from Aspergillus terreus and evolution of templates for the cyclization of farnesyl diphosphate. Biochemistry 2007, 46, 1941-1951. [CrossRef]

67. Lodeiro, S.; Xiong, Q.; Wilson, W.K.; Ivanova, Y.; Smith, M.L.; May, G.S.; Matsuda, S.P.T. Protostadienol biosynthesis and metabolism in the pathogenic fungus Aspergillus fumigatus. Org. Lett. 2009, 11, 1241-1244. [CrossRef] [PubMed]

68. Nicholson, M.J.; Koulman, A.; Monahan, B.J.; Pritchard, B.L.; Payne, G.A.; Scott, B. Identification of two aflatrem biosynthesis gene loci in Aspergillus flavus and metabolic engineering of Penicillium paxilli to elucidate their function. Appl. Environ. Microbiol. 2009, 75, 7469-7481. [CrossRef] [PubMed]

69. Nierman, W.C.; Yu, J.; Fedorova-Abrams, N.D.; Losada, L.; Cleveland, T.E.; Bhatnagar, D.; Bennett, J.W.; Dean, R.; Payne, G.A. Genome sequence of Aspergillus flavus NRRL 3357, a strain that causes aflatoxin contamination of food and feed. Genome Announc. 2015, 3, e00168-15. [CrossRef]

70. Mitsuhashi, T.; Rinkel, J.; Okada, M.; Abe, I.; Dickschat, J.S. Mechanistic characterization of two chimeric sesterterpene synthases from Penicillium. Chem. A Eur. J. 2017, 23, 10053-10057. [CrossRef] [PubMed]

71. Calvert, M.J.; Ashton, P.R.; Allemann, R.K. Germacrene A is a product of the aristolochene synthase-mediated conversion of farnesylpyrophosphate to aristolochene. J. Am. Chem. Soc. 2002, 124, 11636-11641. [CrossRef] [PubMed] 
72. Young, C.; McMillan, L.; Telfer, E.; Scott, B. Molecular cloning and genetic analysis of an indole-diterpene gene cluster from Penicillium paxilli. Mol. Microbiol. 2001, 39, 754-764. [CrossRef]

73. Pinedo, C.; Wang, C.M.; Pradier, J.M.; Dalmais, B.; Choquer, M.; Le Pêcheur, P.; Morgant, G.; Collado, I.G.; Cane, D.E.; Viaud, M. Sesquiterpene synthase from the botrydial biosynthetic gene cluster of the phytopathogen Botrytis cinerea. ACS Chem. Biol. 2008, 3, 791-801. [CrossRef]

74. Izquierdo-Bueno, I.; Moraga, J.; Cardoza, R.E.; Lindo, L.; Hanson, J.R.; Gutiérrez, S.; Collado, I.G. Relevance of the deletion of the Tatri4 gene in the secondary metabolome of Trichoderma arundinaceum. Org. Biomol. Chem. 2018, 16, 2955-2965. [CrossRef] [PubMed]

75. Abe, I.; Naito, K.; Takagi, Y.; Noguchi, H. Molecular cloning, expression, and site-directed mutations of oxidosqualene cyclase from Cephalosporium caerulens. Biochim. Biophys. Acta Gene Struct. Expression 2001, 1522, 67-73. [CrossRef]

76. Schmidhauser, T.J.; Lauter, F.R.; Schumacher, M.; Zhou, W.; Russo, V.E.A.; Yanofsky, C.B. Characterization of al-2, the phytoene synthase gene of Neurospora Crassa. J. Biol. Chem. 1994, 269, 12060-12066.

77. Young, C.A.; Felitti, S.; Shields, K.; Spangenberg, G.; Johnson, R.D.; Bryan, G.T.; Saikia, S.; Scott, B. A complex gene cluster for indole-diterpene biosynthesis in the grass endophyte Neotyphodium lolii. Fungal Genet. Biol. 2006, 43, 679-693. [CrossRef]

78. Shaw, J.J.; Berbasova, T.; Sasaki, T.; Jefferson-George, K.; Spakowicz, D.J.; Dunican, B.F.; Portero, C.E.; Marváez-Trujillo, A.; Strobel, S.A. Identification of a fungal 1,8-cineole synthase from Hypoxylon sp. with specificity determinants in common with the plant synthases. J. Biol. Chem. 2015, 290, 8511-8526. [CrossRef]

79. Zhou, J.S.; Ji, S.L.; Ren, M.F.; He, Y.L.; Jing, X.R.; Xu, J.W. Enhanced accumulation of individual ganoderic acids in a submerged culture of Ganoderma lucidum by the overexpression of squalene synthase gene. Biochem. Eng. J. 2014, 90, 178-183. [CrossRef]

80. Ronquist, F.; Huelsenbeck, J.P. MrBayes 3: Bayesian phylogenetic inference under mixed models. Bioinformatics 2003, 19, 1572-1574. [CrossRef] [PubMed]

81. Price, M.N.; Dehal, P.S.; Arkin, A.P. FastTree 2-Approximately Maximum-Likelihood trees for large alignments. PLoS ONE 2010, 5, e9490. [CrossRef]

82. Guindon, S.; Dufayard, J.F.; Lefort, V.; Anisimova, M.; Hordijk, W.; Gascuel, O. New algorithms and methods to estimate Maximum-Likelihood phylogenies: Assessing the performance of PhyML 3.0. Syst. Biol. 2010, 59, 307-321. [CrossRef]

83. Abascal, F.; Zardoya, R.; Posada, D. ProtTest: Selection of best-fit models of protein evolution. Bioinformatics 2005, 21, 2104-2105. [CrossRef]

84. Whelan, S.; Goldman, N. A general empirical model of protein evolution derived from multiple protein families using a Maximum-Likelihood approach. Mol. Biol. Evol. 2001, 18, 691-699. [CrossRef] [PubMed]

85. Zapparata, A.; Da Lio, D.; Somma, S.; Vicente Muñoz, I.; Malfatti, L.; Vannacci, G.; Moretti, A.; Baroncelli, R.; Sarrocco, S. Genome sequence of Fusarium graminearum ITEM 124 (ATCC 56091), a mycotoxigenic plant pathogen. Genome Announc. 2017, 5, e01209-17. [CrossRef]

86. Logemann, J.; Schell, J.; Willmitzer, L. Improved method for the isolation of RNA from plant tissues. Anal. Biochem. 1987, 163, 16-20. [CrossRef]

87. Livak, K.J.; Schmittgen, T.D. Analysis of relative gene expression data using real-time quantitative PCR and the $2^{-\Delta \Delta C T}$ method. Methods 2001, 25, 402-408. [CrossRef]

88. Linscott, K.B.; Niehaus, T.D.; Zhuang, X.; Bell, S.A.; Chappell, J. Mapping a kingdom-specific functional domain of squalene synthase. Biochim. Biophys. Acta Mol. Cell Biol. Lipids 2016, 1861, 1049-1057. [CrossRef]

89. Jeong, A.; Suazo, K.F.; Wood, W.G.; Distefano, M.D.; Li, L. Isoprenoids and protein prenylation: Implications in the pathogenesis and therapeutic intervention of Alzheimer's disease. Crit. Rev. Biochem. Mol. Biol. 2018, 53, 279-310. [CrossRef]

90. Kushiro, T.; Shibuya, M.; Masuda, K.; Ebizuka, Y. Mutational studies on triterpene synthases: Engineering lupeol synthase into $\beta$-amyrin synthase. J. Am. Chem. Soc. 2000, 122, 6816-6824. [CrossRef]

91. Zhao, L.; Zhang, Y. Effects of phosphate solubilization and phytohormone production of Trichoderma asperellum Q1 on promoting cucumber growth under salt stress. J. Integr. Agric. 2015, 14, 1588-1597. [CrossRef]

92. Wendt, K.U.; Schulz, G.E. Isoprenoid biosynthesis: Manifold chemistry catalyzed by similar enzymes. Structure 1998, 6, 127-133. [CrossRef] 
93. Blin, K.; Shaw, S.; Steinke, K.; Villebro, R.; Ziemert, N.; Lee, S.Y.; Medema, M.; Weber, T. antiSMASH 5.0: Updates to the secondary metabolite genome mining pipeline. Nucleic Acids Res. 2019, 47, W81-W87. [CrossRef]

94. De Vries, R.P.; Riley, R.; Wiebenga, A.; Aguilar-Osorio, G.; Amillis, S.; Uchima, C.A.; Anderluh, G.; Asadollahi, M.; Askin, M.; Barry, K.; et al. Comparative genomics reveals high biological diversity and specific adaptations in the industrially and medically important fungal genus Aspergillus. Genome Biol. 2017, 18, 28. [CrossRef]

95. Nakano, C.; Okamura, T.; Sato, T.; Dairi, T.; Hoshino, T. Mycobacterium tuberculosis H37Rv3377c encodes the diterpene cyclase for producing the halimane skeleton. Chem. Commun. 2005, 8, 1016-1018. [CrossRef] [PubMed]

96. Nakano, C.; Hoshino, T. Characterization of the Rv3377c gene product, a type-B diterpene cyclase, from the Mycobacterium tuberculosis H37 genome. ChemBioChem 2009, 10, 2060-2071. [CrossRef]

97. Shinohara, Y.; Takahashi, S.; Osada, H.; Koyama, Y. Identification of a novel sesquiterpene biosynthetic machinery involved in astellolide biosynthesis. Sci. Rep. 2016, 6, 32865. [CrossRef] [PubMed]

98. Starks, C.M. Structural basis for cyclic terpene biosynthesis by tobacco 5-Epi-aristolochene synthase. Science 1997, 277, 1815-1820. [CrossRef]

99. Cane, D.E.; Xue, Q.; Fitzsimons, B.C. Trichodiene synthase. Probing the role of the highly conserved aspartate-rich region by site-directed mutagenesis. Biochemistry 1996, 35, 12369-12376. [CrossRef] [PubMed]

100. Kim, S.; Cheong, J.H.; Yoo, J. Radical cyclization of N-Aziridinylimines 4. Highly efficient synthesis of dl-pentalenene via consecutive carbon-carbon bond formation approach. Synlett 1998, 1998, 981-982. [CrossRef]

101. Ghisalberti, E.L. Detection and isolation of bioactive natural products. In Bioactive Natural Products: Detection, Isolation and Structure Elucidation; Colegate, S.M., Molyneux, R.J., Eds.; CRC Press: Boca Raton, FL, USA, 1993; pp. 15-18.

102. Adelin, E.; Servy, C.; Martin, M.T.; Arcile, G.; Iorga, B.I.; Retailleau, P.; Bonfill, M.; Ouazzani, J. Bicyclic and tetracyclic diterpenes from a Trichoderma symbiont of Taxus baccata. Phytochemistry 2014, 97, 55-61. [CrossRef] [PubMed]

103. Chen, S.; Li, H.; Chen, Y.; Li, S.; Xu, J.; Guo, H.; Liu, Z.; Zhu, S.; Liu, H.; Zhang, W. Three new diterpenes and two new sesquiterpenoids from the endophytic fungus Trichoderma koningiopsis A729. Bioorg. Chem. 2019, 86, 368-374. [CrossRef] [PubMed]

104. Miao, F.P.; Liang, X.R.; Yin, X.L.; Wang, G.; Ji, N.Y. Absolute configurations of unique harziane diterpenes from Trichoderma species. Org. Lett. 2018, 14, 3815-3817. [CrossRef] [PubMed]

105. Song, Y.P.; Fang, S.T.; Miao, F.P.; Yin, X.L.; Ji, N.Y. Diterpenes and sesquiterpenes from the marine algicolous fungus Trichoderma harzianum X-5. J. Nat. Prod. 2018, 81, 2553-2559. [CrossRef]

106. Zhao, D.; Yang, L.; Shi, T.; Wang, C.; Shao, C.; Wang, C. Potent phytotoxic harziane diterpenes from a soft coral-derived strain of the fungus Trichoderma harzianum XS-20090075. Sci. Rep. 2019, 9, 13345. [CrossRef]

107. Tian, G.; Deng, X.; Hong, K. The biological activities of sesterterpenoid-type ophiobolins. Mar. Drugs 2017, 15, 229. [CrossRef]

108. Saikia, S.; Nicholson, M.J.; Young, C.; Parker, E.J.; Scott, B. The genetic basis for indole-diterpene chemical diversity in filamentous fungi. Mycol. Res. 2008, 112, 184-199. [CrossRef]

109. Parker, E.J.; Scott, B. Indole-diterpene biosynthesis in ascomycetous fungi. In Handbook of Industrial Mycology; An, Z., Ed.; Marcel Dekker: New York, NY, USA, 2004; pp. 405-426.

110. Inayati, A.; Sulistyowati, L.; Aini, L.Q.; Yusnawan, E. Antifungal activity of volatile organic compounds from Trichoderma virens. AIP Conference proceedings 2120, 080012. Int. Conf. Biol. Appl. Sci. (Icobas) 2019. [CrossRef]

111. Schmidt-Dannert, C. Biosynthesis of terpenoid natural products in fungi. In Biotechnology of Isoprenoids. Advances in Biochemical Engineering/Biotechnology; Schrader, J., Bohlmann, J., Eds.; Springer: Singapore, 2014; pp. 19-61.

112. Lopez-Gallego, F.; Agger, S.A.; Abate-Pella, D.; Distefano, M.D.; Schmidt-Dannert, C. Sesquiterpene synthases Cop4 and Cop6 from Coprinus cinereus: Catalytic promiscuity and cyclization of farnesyl pyrophosphate geometric isomers. ChemBioChem 2010, 11, 1093-1106. [CrossRef] [PubMed]

113. Gallo, A.; Mulè, G.; Favilla, M.; Altomare, C. Isolation and characterisation of a trichodiene synthase homologous gene in Trichoderma harzianum. Physiol. Mol. Plant Pathol. 2005, 65, 11-20. [CrossRef] 
114. Calvo, A.M.; Wilson, R.A.; Bok, J.W.; Keller, N.P. Relationship between secondary metabolism and fungal development. Microbiol. Mol. Biol. Rev. 2002, 66, 447-459. [CrossRef] [PubMed]

115. Hong, S.Y.; Roze, L.; Linz, J. Oxidative stress-related transcription factors in the regulation of secondary metabolism. Toxins 2013, 5, 683-702. [CrossRef] [PubMed]

116. Fountain, J.C.; Bajaj, P.; Nayak, S.N.; Yang, L.; Pandey, M.K.; Kumar, V.; Jayale, A.S.; Chitikineni, A.; Lee, R.D.; Kemerait, R.C.; et al. Responses of Aspergillus flavus to oxidative stress are related to fungal development regulator, antioxidant enzyme, and secondary metabolite biosynthetic gene expression. Front. Microbiol. 2016, 7, 2048. [CrossRef]

117. Hautbergue, T.; Jamin, E.L.; Debrauwer, L.; Puel, O.; Oswald, I.P. From genomics to metabolomics, moving toward an integrated strategy for the discovery of fungal secondary metabolites. Nat. Prod. Rep. 2018, 35, 147-173. [CrossRef]

118. Wiemann, P.; Sieber, C.M.K.; von Bargen, K.W.; Studt, L.; Niehaus, E.M.; Espino, J.J.; Huß, K.; Michielse, C.B.; Albermann, S.; Wagner, D.; et al. Deciphering the cryptic genome: Genome-wide analyses of the rice pathogen Fusarium fujikuroi reveal complex regulation of secondary metabolism and novel metabolites. PLoS Pathog. 2013, 9, e1003475. [CrossRef]

119. Bualem, B.; Mohamed, B.; Moulay, B. Salinity influence upon activity of Trichoderma harzianum against Botrytis cinerea. Asian J. Plant Pathol. 2015, 9, 158-166. [CrossRef]

120. Hidangmayum, A.; Dwivedi, P. Plant responses to Trichoderma spp. and their tollerance to abiotic stresses: A review. J. Pharmacogn. Phytochem. 2018, 7, 758-766.

Publisher's Note: MDPI stays neutral with regard to jurisdictional claims in published maps and institutional affiliations.

(C) 2020 by the authors. Licensee MDPI, Basel, Switzerland. This article is an open access article distributed under the terms and conditions of the Creative Commons Attribution (CC BY) license (http://creativecommons.org/licenses/by/4.0/). 